\title{
The Application of Ultra High Voltage in the World
}

\author{
Metin Candas, Ozlem Sahin Meric \\ Faculty of Aeronautics and Astronautics, Eskisehir, Turkey \\ Email: mcandas@anadolu.edu.tr, osahin5@anadolu.edu.tr
}

Received February 2015

\begin{abstract}
With rapidly growth in industrial sectors, in order to meet the demand, the usage of Ultra High Voltage (UHV) is needed. High voltage (HV) is between the range of $52 \mathrm{kV}$ and $300 \mathrm{kV}$. In case of voltage above $800 \mathrm{kV}$, it can be defined as UHV. With the development of technologies in the world, it could be seen that Japan, Russia, Italy, Brazil, America (U.S), and Canada began to improve UHV in the 1960s and 1970s. In addition, China, a leader developing country for UHV technologies in the world, started UHV technologies in transmission, in 1980s. Nowadays, seven transmission lines are in operation in China. In this study, the concept of HV and UHV will be introduced. Especially, UHV transmission in the worldwide will be researched. Then, the historical development and current situation of UHV will be analyzed and the assessment for Turkey will be done.
\end{abstract}

\section{Keywords}

\section{Energy, Power Transmission, Ultra High Voltage}

\section{Introduction}

The world's population is getting increased and global energy consumption is growing up. Therefore, the needs of several types of renewable energy resources such as hydropower, wind, sun, tides, geothermal, waves, biomass sources are required besides to coal, fossil fuels, natural gas and minerals. But sometimes generation places of these resources are not close to consumers. For transferring high power from sources of generation to countries or regions which are growing faster is becoming significant [1] [2].

Larger amounts of electric power transferring for longer distances could be required to higher transmission voltage. Nowadays, it could be met by using High Voltage (HV) and Ultra High Voltage (UHV). Ranges of 52 $\mathrm{kV}-300 \mathrm{kV}$ and $800 \mathrm{kV}$ and above are the voltage of HV and UHV, respectively [3].

While transferring energy to longer distances, the more energy losses could be occurred. The energy losses could be prevented by increasing the voltage above $800 \mathrm{kV}$ with UHV transmission lines which achieve efficiency and lower transmission costs [4]. Furthermore, UHV transmission provides to use clean energy sources for producing electricity which is resulted in a reduction of environmental impacts such as emissions, air pollutions and climate changes. Other advantages of UHV technology are: increased transmission capacity, extended transmission distance, reduced transmission losses and also reduced land requirements [5]. 


\section{Development of the UHV Transmission System in the World}

The studies related to UHV transmission technologies began in Russia, Japan, the United States of America (USA), Italy, Canada, and Brazil in 1960s and 1970s. In addition, China started UHVAC transmission projects in 1986. China, India and South Africa have been still studying on UHVDC transmission.

The first UHV studies in Russia (The Former USSR) were appeared in 1970s. At the beginning of the 1990s, $1150 \mathrm{kV}$ AC transmission lines $(2362 \mathrm{~km})$ were established but later voltage level was decreased to $500 \mathrm{kV}$. In addition $1090 \mathrm{~km}$ and $\pm 750 \mathrm{kV}$ DC transmission lines were built in the beginning of 1980s.

In Japan the studies about UHV transmission technology started in 1973 [6]. Tokyo Electric Power Company (TEPCO) constructed to $1100 \mathrm{kV}$ transmission lines which aim to connect power station to crowded countries/regions in 1993 and also in 1999 power sources on the Pacific Ocean were connected with the transmission lines. In 2000s those routes were operated at $550 \mathrm{kV}$ although they were constructed at $1100 \mathrm{kV}$ which could provide 3 to 4 times greater capacity [7].

UHV transmission studies started in 1967 in the USA. Transmitting bulk power, developing system stability and reducing environment impacts were aimed by using new transmission systems. The facilities which performed UHV studies were General Electric Company (GE), the Electric Power Research Institute (EPRI), the American Electric Power Company (AEP), and the Bonneville Power Administration (BPA). In recent years, it could be said that the U.S. has little activity on UHV transmission technologies as compared with China [5].

The CU Powerline and Square Butte Projects which were included North American grid HVDC projects were studied for delivering the power among the cities such as From North Dakota to Minneapolis, Minnesota and Duluth, Minnesota, respectively.

Two projects called Neptune and Trans Bay Cable were constructed by Siemens Company. Neptune project proposed to link Long Island and New Jersey transfers 660 MW over 65 miles. The second project, a 53 miles 400 MW Trans Bay Cable carries bulk power into San Francisco Bay. HV DC and AC transmission projects are Illinois River Project, Rock Island Clean Line LLC Project and the other transmission line projects are The Plains and Eastern Clean Line Transmission Project, The Centennial West Clean Transmission Line Project and The Grain Belt Express Clean Line Transmission Project which are planned to be done [8].

In Italy, UHV studies were done in the laboratories and testing stations that A $700 \mathrm{kV}$ generator was used in 1970s.

In Canada, at the HV laboratory of Hydro-Que'bec Institute of Research (IREQ) studies related to voltages up to $1500 \mathrm{kV}$ were performed. Test studies such as Corona, electric field and ion current performance were researched in the range of $\pm 600 \mathrm{kV}$ to $1200 \mathrm{kV}$ DC and $1500 \mathrm{kV}$ AC. Also at Magdalen Islands, test line was built vibration performance test of 6 and 12 conductor bundles and development of spacer dampers [6]. The Project, 550 miles and 3.8 GW of capacity, called The Nelson River in Canada links to hydroelectric sources which are located in Northern Manitoba to population centers in Southern Manitoba. Between 1990 and 1992, The Quebec-New England Project, have over 930 miles and 2 GW of capacity, was instructed from Hudson Bay (in Quebec) to Massachusetts (near Boston) [8].

FACTS, a technology that enforces the weak AC grids and stabilizes AC transmission to longer distances, is the world's biggest project in India (at Purnea and Gorakhpur). Hydropower from Bhutan over long distances are achieved by this Project [9]. India is establishing lines with ultrahigh voltages of $\pm 800 \mathrm{kV}$. Nowadays India has still been studying on the world's the first ultrahigh voltage power transmission lines at $1200 \mathrm{kV}$ with participants such as Bharat Heavy Electricals Ltd, Vijai Electricals Ltd, Crompton Greaves, Larsen \& Toubro, Siemens, Alstom India, KEC International, Supreme \& Co [10].

In Brazil, transmitting the bulk power from Amazon Basin to the load centers at far distances was required using transmission lines above $1000 \mathrm{kV}$. Since 1984, Brazil has used to the world's highest voltage and capacity system called The Itaipu transmission line at $\pm 600 \mathrm{kV}$ [6]. In 2014, $2400 \mathrm{~km}$ HVDC link was instructed in Brazil. It is the world's longest link for carrying $3150 \mathrm{MW}$ of power in the northwest to Sao Paulo [11]. In 2014, a consortium led by SGCC won a 30-year concession to build and operate a 2000-km (1240-mile), $800 \mathrm{kV}$ UHV line in Brazil. The transmission system will carry power from the Belo Monte dam in northern Brazil to the major consumption centers in the southeast [12].

China is a leader developing country for UHV technologies in the World. The largest number of HVDC links are available in China. Because of faster developing industries, demand of power generation and power transmission is increasing. Due to prevent high energy losses, $800 \mathrm{kV}-1100 \mathrm{kV}$ UHDC and $1000 \mathrm{kV}$ UHVAC vol- 
tage levels are preferred. Seven transmission lines are in operation in China [9] [12].

In December 2014, the world's largest power grid operator, State Grid Corporation of China (SGCC), declared that 13 UHV transmission lines are planned to built by 2017 and 27 UHV transmission lines are intended to construct by 2020 [13] [14]. UHV projects in China are summarized in terms of in operation, under construction and waiting final approval (Figure 1) [15].

As mentioned before, Russia, Japan, the U.S. and Italy had performed studies and tests related to UHV transmission between the 1960s and 1990s. By the reason of political factors and a decrease in demand, projects about UHV has not been completed [16].

\section{The Current Situation of Energy Transmission in Turkey}

Turkey is located in an important location that connects the Asia and Europe. Turkey's population is growing faster and also the industry is developing. Turkey is the second country in increase of electricity demand in the world also the first in Europe [17].

Due to increase in electric power consumption, the need of power generation and power transmission is occurred. Turkish energy resources are hard coal, lignite, asphalt, bituminous schist, hydropower, oil, natural gas, geothermal and solar energy, wood, as well as animal and plant wastes [18].

In 1902, the first hydroelectric power station (2 kW) was constructed in Tarsus, Adana. In 1913 the first Alibeyköy Silahtarağa plant in Istanbul was built for lighting purposes. $66 \mathrm{kV}$ energy transmission from Zonguldak to Istanbul in 1948. Voltage level was increased at $154 \mathrm{kV}$ and a transmission line were constructed between Ereğli-Karadeniz and Istanbul in 1952. And in 1960, power transmission at $380 \mathrm{kV}$ was begun and in 1971 at $380 \mathrm{kV}$ transmission line was used from Keban to Ankara [3] [19].

The voltages levels, nominal voltage and permissible maximum operating voltage, in Turkey are given in Table 1. Today, Extra High Voltage (EHV) levels defined at $380 \mathrm{kV}$ nominal and $420 \mathrm{kV}$ permissible maximum operating voltage. In Turkey, UHV voltage levels has not been defined yet.

A new HV transmission line will connect two cities, Bursa and Kocaeli, which are rapidly developing cities in

\begin{tabular}{|c|c|c|c|c|}
\hline Status & Type & 2012 & 2013 & 2014 \\
\hline \multirow{9}{*}{ Commissioned } & \multirow{3}{*}{$\mathrm{AC}$} & $\begin{array}{c}\text { Jindongnan-Nanyang- } \\
\text { Jingmen }\end{array}$ & $\begin{array}{c}\text { Jindongnan-Nanyang- } \\
\text { Jingmen }\end{array}$ & $\begin{array}{l}\text { Jindongnan-Nanyang- } \\
\text { Jingmen }\end{array}$ \\
\hline & & & $\begin{array}{c}\text { Huainan-Zhebei- } \\
\text { Shanghai }\end{array}$ & $\begin{array}{c}\text { Huainan-Zhebei- } \\
\text { Shanghai }\end{array}$ \\
\hline & & & & Fuzhou-North Zhejiang \\
\hline & \multirow{6}{*}{ DC } & Yunnan-Guangdong & Yunnan-Guangdong & Yunnan-Guangdong \\
\hline & & Xiangjiaba-Shanghai & Xiangjiaba-Shanghai & Xiangjiaba-Shanghai \\
\hline & & Jinping-Sunan & Jinping-Sunan & Jinping-Sunan \\
\hline & & & Nuozhadu-Guangdong & Nuozhadu-Guangdong \\
\hline & & & & $\begin{array}{c}\text { Southern Hami- } \\
\text { Zhengzhou }\end{array}$ \\
\hline & & & & Xiluodu-Zhejiang \\
\hline \multirow{5}{*}{ Under construction } & \multirow[b]{2}{*}{$\mathrm{AC}$} & $\begin{array}{l}\text { Huainan-Zhebei- } \\
\text { Shanghai }\end{array}$ & Fuzhou-North Zhejiang & $\begin{array}{l}\text { Huainan-Nanjing- } \\
\text { Shanghai }\end{array}$ \\
\hline & & & & Ya'an-Wuhan \\
\hline & \multirow{3}{*}{ DC } & Nuozhadu-Guangdong & $\begin{array}{l}\text { Southern Hami- } \\
\text { Zhengzhou }\end{array}$ & Jiuquan-Hunan \\
\hline & & $\begin{array}{l}\text { Southern Hami- } \\
\text { Zhengzhou }\end{array}$ & Xiluodu-Zhejiang & Ningdong-Zhejiang \\
\hline & & Xiluodu-Zhejiang & & \\
\hline \multirow{4}{*}{ Awaiting final approval } & \multirow[t]{2}{*}{$A C$} & & $\begin{array}{l}\text { Huainan-Nanjing- } \\
\text { Shanghai }\end{array}$ & \\
\hline & & & Ya'an-Wuhan & \\
\hline & \multirow{2}{*}{ DC } & & Jiuquan-Hunan & \\
\hline & & & Ningdong-Zhejiang & \\
\hline
\end{tabular}

Figure 1. UHV projects in China [15]. 
Table 1. Voltages levels in Turkey [19].

\begin{tabular}{ccc}
\hline & Nominal voltage (kV) & Permissible max. Operating voltage (kV) \\
\hline High Voltage & 66 & 36 \\
& 154 & 72 \\
Extra High Voltage & 380 & $420(400)$ \\
\hline
\end{tabular}

Turkish industry. The Turkish Electricity Transmission Company will built Gemlik-İzmit $380 \mathrm{kV}$ energy transmission line Project. Furthermore, $53 \mathrm{~km}$ transmission line is planned from Bursa's Orhangazi and İznik districts and Karamursel, Başiskele, Gölcük, Izmit and Kartepe districts of Kocaeli. In this Project, overhead lines will be chosen and in 2015 January, it is declared that after 16 months the lines will be completed [20].

On 8th January 2015, it is declared that the submarine cable EHV Project called $380 \mathrm{kV}$ Lapseki-sütlüce across the Dardanelles Strait is constructed [21].

Energy Ministry of Turkey is cooperation with European Bank for Reconstruction and Development (EBRD) in order to improve the Turkey's first renewable energy action plan. Until 2023 Turkey is proposed to increase total capacity of sources, allows to add $34 \mathrm{GW}$ of hydropower, $20 \mathrm{GW}$ of wind energy, $5 \mathrm{GW}$ of solar energy, 1 GW of geothermal energy and $1 \mathrm{GW}$ of biomass, to $30 \%$ [22].

\section{Conclusions}

Larger amounts of electric power transferring for longer distances could be required to higher transmission voltage. Nowadays, it could be met by using High Voltage (HV) and Ultra High Voltage (UHV). Ranges of $52 \mathrm{kV}$ $300 \mathrm{kV}$ and $800 \mathrm{kV}$ and above are the voltage of HV and UHV, respectively [3].

The studies related to UHV transmission technologies began in Russia, Japan, the United States of America (USA), Italy, Canada, and Brazil in 1960s and 1970s. In addition, China started UHVAC transmission projects in 1986. China, India and South Africa have been still studying on UHVDC transmission [6]. Today, China is the leadership for developing UHV transmission technology in the world. Seven transmission lines are in operation and 27 transmission lines are planned to be constructed by 2020. Russia, Japan, the U.S. and Italy had performed studies and tests related to UHV transmission, but, by the reason of political factors and a decrease in demand, projects about UHV have not been completed [16]. In Turkey, only EHV is being used at $400 \mathrm{kV}$. UHV voltage levels have not been defined yet. Turkey has been still studying on HV projects. For instance, a new HV transmission line will connect two cities, Bursa and Kocaeli, which are rapidly developing cities in Turkish industry. The Turkish Electricity Transmission Company will build Gemlik-Izmit 380 kV energy transmission line project. Moreover, $53 \mathrm{~km}$ transmission line is planned from Bursa's Orhangazi and Iznik districts and Karamursel, Başiskele, Gölcük, Izmit and Kartepe districts of Kocaeli. In this project, overhead lines will be chosen and in 2015 January, it is declared that after 16 months the lines will be completed [20].

\section{References}

[1] Asplund, G. (2015) Ultra High Voltage Transmission, Energy Efficient Grids, ABB Review 2/2007. http://www05.abb.com/global/scot/scot271.nsf/veritydisplay/9e16e26d65ab7339c12572fe004deb21/\$file/22-272m733 eng72dpi.pdf

[2] http://www.alstom.com/grid/products-and-services/engineered-energy-solutions/hvdc-transmission-systems/HVDC-Ult ra-High-Voltage/

[3] Kalenderli, Ö. (2015) Yüksek Gerilim nedir? Neden gereklidir? Istanbul Technical University. http://web.itu.edu.tr/kalenderli/Yuksek_Gerilim_Nedir_Kalenderli.pdf

[4] http://www.forbes.com/sites/realspin/2014/09/18/ultra-high-voltage-transmission-can-break-chinas-cycle-of-energy-de pendence/

[5] http://www.cleanenergyactionproject.com/CleanEnergyActionProject/Blog/Entries/2011/4/20_Ultra_High_Voltage_\% 28UHV\%29_Transmission_Could_be_Our_Renewable_Energy_Interstate.html

[6] Huang, D., Shu, Y., Ruan, J. and Hu, Y. (2009) Ultra High Voltage Transmission in China: Developments, Current Status and Future Prospects. Proceedings of the IEEE, 97.

[7] Hidaka, K. (2010) International Standardization of $1100 \mathrm{kV}$ UHV Transmission Technologies Originating from Japan, EINA No.17. http://eina.ws/no17/EINA_No17p16-19.pdf 
[8] Ragheb, M. (2014) High Voltage Direct Current HVDC for Wind Power.

[9] Hammons, T.J., Lescale, V.F., Uecker, K., Haeusler, M., Retzmann, D., Staschus, K. and Lepy, S. (2012) State of the Art in Ultrahigh-Voltage Transmission. Proceedings of the IEEE, 100. http://dx.doi.org/10.1109/JPROC.2011.2152310

[10] Pillai, V. (2014) Electrical Monitor, 9, 34.

[11] www.world-nuclear.org/info/Current-and-Future-Generation/Electricity-Transmission-Grids

[12] http://www.reuters.com/article/2014/06/19/us-china-electricity-grid-kemp-idUSKBN0EU19B20140619

[13] http://en.xinfinance.com/Industries/Utilities/2014/15901.shtml

[14] http://www.chinacoalintl.com/news-1040\#.VOofzC5JfEY

[15] http://www.lantaugroup.com/files/tlgchina_uhv_may14.pdf

[16] http://news.xinhuanet.com/english/china/2015-02/11/c 133986594.htm

[17] http://www.enerji.gov.tr/File/?path=ROOT\%2f1\%2fDocuments\%2fStratejik+Plan\%2fETKB+2015-2019+Stratejik+Pl ani.pdf

[18] Sözen, A., Arcaklioğlu, E. and Özkaymak M. (2005) Turkey’s Net Energy Consumption. Applied Energy, 81, $209-221$. http://dx.doi.org/10.1016/j.apenergy.2004.07.001

[19] Bolat, S. What Is High Voltage? Why Is It Needed? Eastern Mediterranean University, Electric and Electronic Department. http://faraday.ee.emu.edu.tr/eeng451/HIGH\%20VOLTAGE-\%20intro.pdf

[20] https://realestatenews.com.tr/new-high-voltage-transmission-line-between-bursa-and-kocaeli-on-the-way

[21] http://www.globaltransmission.info/archive main.php?id=18\&region=4

[22] https://realestatenews.com.tr/turkey-and-ebrd-develop-renewable-energy-action-plan/ 